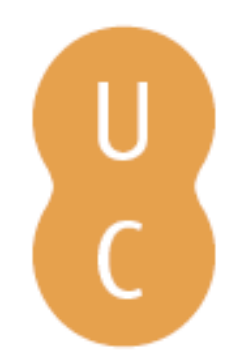

\title{
nommalina
}

\section{The Elements of Euclides: the Cornerstone of Modern Mathematics}
Autor(es):
Silva, Jorge Nuno; Pinto, Helder
Edições Afrontamento; CITCEM - Centro de Investigação Clássicos e Humanísticos; Alexandria University; Imprensa da Universidade de Coimbra
Publicado por: Transdisciplinar «Cultura, Espaço e Memória»; Centro de Estudos
URL
URI:http://hdl.handle.net/10316.2/36181
DOI:
DOI:http://dx.doi.org/10.14195/978-989-26-0966-9_15
Accessed : $\quad$ 26-Apr-2023 09:40:26

A navegação consulta e descarregamento dos títulos inseridos nas Bibliotecas Digitais UC Digitalis, UC Pombalina e UC Impactum, pressupõem a aceitação plena e sem reservas dos Termos e Condições de Uso destas Bibliotecas Digitais, disponíveis em https://digitalis.uc.pt/pt-pt/termos.

Conforme exposto nos referidos Termos e Condições de Uso, o descarregamento de títulos de acesso restrito requer uma licença válida de autorização devendo o utilizador aceder ao(s) documento(s) a partir de um endereço de IP da instituição detentora da supramencionada licença.

Ao utilizador é apenas permitido o descarregamento para uso pessoal, pelo que o emprego do(s) título(s) descarregado(s) para outro fim, designadamente comercial, carece de autorização do respetivo autor ou editor da obra.

Na medida em que todas as obras da UC Digitalis se encontram protegidas pelo Código do Direito de Autor e Direitos Conexos e demais legislação aplicável, toda a cópia, parcial ou total, deste documento, nos casos em que é legalmente admitida, deverá conter ou fazer-se acompanhar por este aviso.

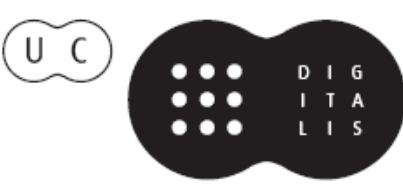




\title{
THE ELEMENTS OF EUCLIDES: THE CORNERSTONE OF MODERN MATHEMATICS
}

\author{
JORGE NUNO SILVA \\ HELDER PINTO
}

University of Lisbon.

\begin{abstract}
Greek mathematics occupies a central place in the History of Mathemat$i c s$. Its relevance rests on its methods, more than on its mathematical results. In this text we try to give an idea how mathematics changed from a collection of problem solving algorithms into a building of knowledge, with special foundations and methods of validation. Euclid's Elements embodies the new mathematical tradition and today, 2300 years after being written, it is still the paradigm of high quality mathematical writing.
\end{abstract}

Greek mathematics occupies a central place in the History of Mathematics. Its relevance transcends its mathematical results - a present day high school graduate should know most of the theorems found by the ancient Greek mathematicians -, being the paradigm for the present way of doing mathematics.

The ancient Greeks, using logically based arguments similar to our own, produced a kind of mathematics unheard of before them. Their appearance can be considered the founding moment for modern mathematics. Greek mathematics stands as a decisive moment, matched only by the appearance of writing or, for the Western civilization, the life of Jesus Christ. The corresponding «Bible» is the book The Elements, by Euclid (about 300 B.C.); organized in thirteen chapters, it was the main mathematical reference work for over two millennia.

«Euclid's influence was outstanding, and by the young student that struggled with geometry, the subject of study was referred to by another name: Euclid. He was their subject 
matter. Until very recently, almost all students were familiar with the expression QED»Quod Erat Demonstrandum -, «that finished the proofs of the theorems. Still today, high school geometry is directly based on Euclid's text $»^{1}$.

The Elements - «the most important text of Greek times, and probably of all time ${ }^{2}-$ and its author are clearly intertwined, one reason for that being the fact that we do not know much about Euclid's life and his other writings: «Essentially nothing is known about the life of the author of the Elements, it is generally assumed that Euclid taught and wrote at the Museum and Library at the Alexandria» ${ }^{3}$.

The Elements survived until today, although no copy of Euclid's times lived that long. However, «has appeared in more editions than any other except the Bible. It has been translated into countless languages and has been continuously in print in one country or another nearly since the beginning of printing» ${ }^{4}$.

As mentioned before, Greek Mathematics became the paradigm for proper mathematics. Before them, the Babylonian and Egyptian civilizations flourished. It is generally accepted that some of the knowledge of those cultures migrated to Greece, but the mathematical methods changed radically.

The methodology in the Elements, however, is entirely different from that of the Egyptians and Babylonians. Mathematics in earlier cultures always involved numbers and measurement. Numerical algorithms for solving various problems are prominent. The mathematics of Euclid, however, is completely nonarithmetical. There are no numbers used in the entire work aside from a few small positive integers. There is also no measurement. Various geometrical objects are compared, but not by use of numerical measures. There are no cubits or acres or degrees. The only measurement standard - for angles - is the right angle ${ }^{5}$.

The concept of proof, which stands today as the basis of the mathematical corpus, did not exist in those ancient civilizations. The results were organized by analogy of particular problems, which did not lead to new discoveries. The Babylonians and the Egyptians never produced a consistent body of mathematical knowledge, they were just competent to solve a finite collection of specific problems. The best they did, in generalizing and abstracting from particular resolutions was to give recipes as to solve similar problems. Greek mathematics left this approach behind. Mathematical results became supported by proofs, which started from first principles and were based on solid arguments.

\footnotetext{
${ }^{1}$ SEYMOR-SMITH, 2007: 109.

${ }^{2}$ KATZ, 2004: 36.

${ }^{3}$ KATZ, 2004, 37.

${ }^{4}$ KATZ, 2004: 36.

${ }^{5}$ KATZ, 2004: 38.
} 
The theorems in The Elements were not, we believe, found by Euclid. His outstanding contribution materialized in its conceptual organization. As Burton put it:

Anyone familiar with the intellectual process realizes that the content of the Elements could not be the effort of a single individual. Unfortunately, Euclid's achievement has so dimmed our view of those who preceded him that it is not possible to say how far he advanced beyond their preparatory work. Few, if any, of the theorems established in the Elements are of his own discovery; Euclid's greatness lies not so much in the contribution of original material as in the consummate skill with which he organized a vast body of independent facts into the definitive treatment of Greek geometry and number theory. The particular choice of axioms, the arrangement of the propositions, and the rigor of demonstration are personally his own. One result follows another in strict logical order, with a minimum of assumptions and very little that is superfluous. So vast was the prestige of the Elements in the ancient world that its author was seldom referred by name but rather by the title "The Writer of the Elements» or sometimes simply «The Geometer» ${ }^{6}$.

It is evident that the conceptual leap necessary to bridge from casuistic mathematics to abstraction is enormous. The fact that this step was actually given shows us that Greek civilization was culturally ripe enough. The starting point was the logic and philosophical traditions, that go back to 6th century B.C. when Thales and, after him, Pythagoras, started looking at the physical world through mathematical spectacles, on one hand, and understood the higher level of mathematical truth. Aristotle, later, raised the techniques of valid deduction to new levels, and gave directions along which new knowledge could be obtained.

The Elements, no copy of which from Euclid's times reached us, travelled through a crooked path.

There are no copies of the Elements dating from Euclid's time. (...) Copies of the work were, however, made regularly from Euclid's time onward. Various editors made emendations, added comments, or put new lemmas. In particular, Theon of Alexandria ( $4^{\text {th }}$ century CE) was responsible for one important new edition. Most of the extant manuscripts of Euclid's Elements are copies of Theon's edition. The earliest such copy still in existence is in the Bodleian Library of Oxford University an dates from 888. There is, however, one manuscript in the Vatican Library, dating from the tenth century, that is not a copy of Theon's edition but of an earlier version. A detailed comparison of this manuscript with several old manuscript copies of Theon's version allowed the Danish scholar J. L. Heiberg to compile a definitive Greek version in the 1880s, as close to the Greek original as he believed was possi$b l e^{7}$.

\footnotetext{
${ }^{6}$ BURTON, 2007: 147

${ }^{7}$ KATZ, 2004: 37.
} 
In early 20th century Heiberg's text was eventually translated into English by Thomas Heath (with extensive commentaries), and it is this work that serves still today as the main reference on the subject. However, throughout the centuries, several versions of The Elements co-existed in the western world.

The first complete Latin translation of the Elements were not made from the Greek but from the Arabic. In the eighth century, a number of Byzantine manuscripts of Greek works were translated by the Arabians, and in 1120 the English scholar Adelard of Bath, made a Latin translation of the Elements from one of these older Arabian translations. Other Latin translations were made from the Arabian by Gherardo of Cremona (1114-1187) and, 150 years after Adelard, by Johannes Campanus. The first printed edition of the Elements was made at Venice in 1482 and contained Campanus' translation. This very rare book was beautifully executed and was the first mathematical book of any consequence to be printed ${ }^{8}$.

It is remarkable that the first mathematical book to be printed was already eighteen hundred years old. This shows how important it was. In Portuguese, the first translation, incomplete, of this work was made in the University at Coimbra in $1855^{9}$. It was based on a Latin version of Frederico Commandino from the 16th century.

In the following table (see next page), based on Heath ${ }^{10}$ and Sá ${ }^{11}$, we summarize the content of The Elements.

The first six books got wider circulation, being focused on basic plane. On the other hand, we should underline that this work does not cover all the geometry known by then by the Greek. It is likely that Euclid left out most of his mathematical knowledge. The focus on this work is on the organization and presentation of the material, not so much on mathematical sophistication.

There is no new discovery attributed to him, but he was noted for expository skill. This is the key to the success of his greatest work, the Elements. It was frankly a textbook and by no means the first one. [...] Proclus describes the Elements as bearing to the rest of mathematics the same sort of relation as that which the letters of the alphabet have in relation to language. Were the Elements intended as an exhaustive store of information, the author probably would have included references to other authors, statements of recent research, and informal explanations. As it is, the Elements is austerely limited to the business in hand the exposition in logical order of the fundamentals of elementary mathematics ${ }^{12}$.

\footnotetext{
${ }^{8}$ EVES, 1964: 114.

${ }^{9}$ See $<$ http://www.mat.uc.pt/ jaimecs/euclid/elem.html>.

${ }^{10}$ HEATH, 1956.

${ }^{11}$ SÁ, 2000: 251-252.

${ }^{12}$ BOYER, 1991: 104.
} 
Few books have been more important to the thought and education of the Western world than Euclid's Elements. Scarcely any other book save the Bible has been more widely circulated or studied; for 20 centuries, the first six books were the student's usual introduction to geometry. Over a thousand editions of the Elements have appeared since the first printed version in 1482; and before that, manuscript copies dominated much of the teaching of mathematics in Europe ${ }^{13}$.

\begin{tabular}{|c|c|c|c|}
\hline Book & \multicolumn{2}{|l|}{ Content } & \multirow{7}{*}{$\begin{array}{l}\text { Plane geometry } \\
\text { (proportion theory can } \\
\text { also be applied to three- } \\
\text { dimensional geometry) }\end{array}$} \\
\hline 1 & $\begin{array}{l}\text { Congruence of triangles. } \\
\text { Parallel lines. } \\
\text { Pythagoras Theorem and converse. }\end{array}$ & $\begin{array}{l}23 \text { definitions } \\
5 \text { postulates } \\
5 \text { common notions } \\
48 \text { propositions }\end{array}$ & \\
\hline II & Geometric algebra. & $\begin{array}{l}14 \text { propositions } \\
2 \text { definitions }\end{array}$ & \\
\hline III & Geometry of the circle. & $\begin{array}{l}11 \text { definitions } \\
37 \text { propositions }\end{array}$ & \\
\hline IV & Polygons inscribed and circumscribed to circles. & $\begin{array}{l}7 \text { definitions } \\
16 \text { propositions }\end{array}$ & \\
\hline V & Eudoxo's theory of proportions. & $\begin{array}{l}18 \text { definitions } \\
25 \text { propositions }\end{array}$ & \\
\hline $\mathrm{Vl}$ & Applications to plane geometry. & $\begin{array}{l}11 \text { definitions } \\
37 \text { propositions }\end{array}$ & \\
\hline VII & $\begin{array}{l}\text { Introduction to number theory. } \\
\text { Euclidean algorithm to find the greatest common } \\
\text { divisor of two numbers. }\end{array}$ & $\begin{array}{l}22 \text { definitions } \\
39 \text { propositions }\end{array}$ & \\
\hline VIII & Geometric progressions. & 27 propositions & (1) \\
\hline IX & $\begin{array}{l}\text { Fundamental Theorem of Arithmetic. } \\
\text { Proof of infinitude of prime numbers. }\end{array}$ & 36 propositions & \\
\hline $\mathrm{x}$ & Irrationals. & $\begin{array}{l}16 \text { definitions } \\
115 \text { propositions }\end{array}$ & \\
\hline XII & Solids. & $\begin{array}{l}28 \text { definitions } \\
39 \text { propositions }\end{array}$ & Three-dimensional \\
\hline XII & Volume calculations using exhausting. & 18 propositions & geometry \\
\hline XIII & Properties of the five Platonic solids. & 18 propositions & \\
\hline
\end{tabular}

${ }^{13}$ BURTON, 2007: 145. 
In Portugal, namely in the University of Coimbra, Euclid was used in teaching as well. As a matter of fact, until the Reform of Pombal, in 1772, Euclid accounted for almost the whole curriculum.

Besides this didactical use throughout the centuries, and its main justification, the main characteristic of the Elements is its organization.

Euclid was aware that to avoid circularity and provide a starting point, certain facts about the nature of the subject had to be assumed without proof. These assumed statements, from which all others are to be deduced as logical consequences, are called the «axioms» or "postulates». In the traditional usage, a postulate was viewed as a «self-evident truth»; the current, more skeptical view is that postulates are arbitrary statements, formulated abstractly with no appeal to their «truth» but accepted without further justification as a foundation for reasoning. They are in a sense the «rules of the game» from which all deductions may proceed - the foundation on which the whole body of theorems rests ${ }^{14}$.

The rigorous and organized mathematical field was born in Greece, as we saw. The mathematical reasoning of today is not essentially different from Euclid's. His influence was widespread in space and time:

Biographies of many famous mathematicians indicate that Euclid's work provided their initial introduction to mathematics, that in fact motivated them to become mathematicians. It provided them with a model of how "pure mathematics» should be written, with precise definitions, well-thought-out axioms, carefully stated theorems, and logically coherent proofs $s^{15}$.

Even though the amount of new discoveries nowadays is enormous, the techniques that lead to these findings and their proofs are two millennia old.

Euclid tried to build the whole edifice of Greek geometrical knowledge, amassed since the time of Thales, on five postulates of a specifically geometric nature and five axioms that were meant to hold for all mathematics; the latter he called common notions. (The first three postulates are postulates of construction, which assert what we are permitted to draw.) He then deduced from these 10 assumptions a logical chain of 465 propositions, using them like stepping-stones in an orderly procession from one proved proposition to another. The marvel is that so much could be obtained from so few sagaciously chosen axioms ${ }^{16}$.

\footnotetext{
${ }^{14}$ BURTON, 2007: 147.

${ }^{15}$ KATZ, 2004: 36.

${ }^{16}$ BURTON, 2007: 148.
} 
The order is so well chosen that usually the proof of a proposition is based on the previous one. The reader witnesses the construction of an incredible mathematical building. So accomplished the Elements were in its structure that no other similar work took its place during so many centuries.

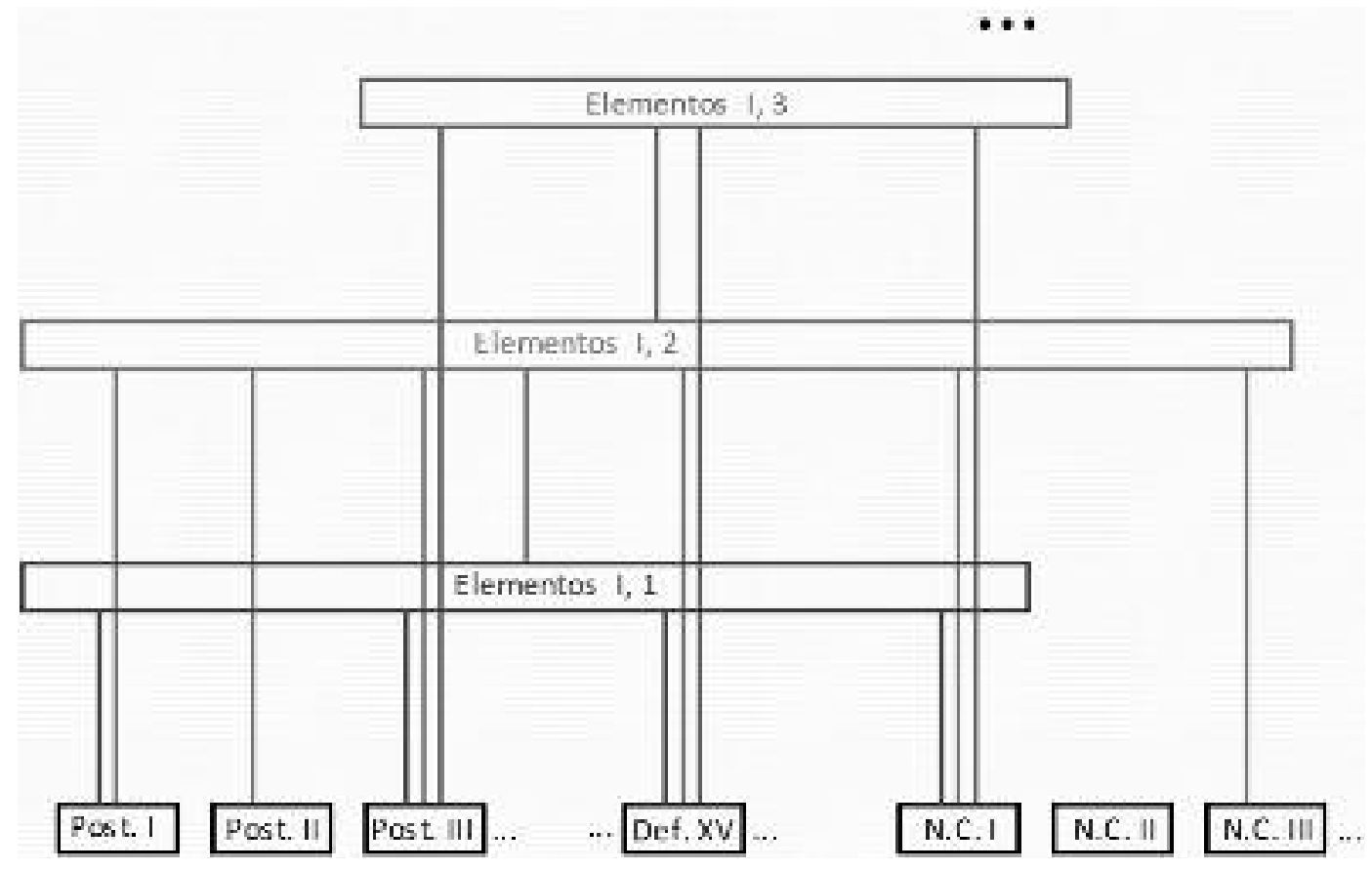

Fig. 1: The structure of dependencies of the first three propositions of the Elements.

Euclid starts with the:

\section{DEFINITIONS}

1. A point is that which has no part.

2. A line is breadthless length.

3. The extremities of a line are points.

4. A straight line is a line which lies evenly with the points on itself.

5. A surface is that which has length and breadth only.

6. The extremities of a surface are lines.

7. A plane surface is a surface which lies evenly with the straight lines on itself.

8. A plane angle is the inclination to one another of two lines in a plane which meet one another and do not lie in a straight line.

9. And when the lines containing the angle are straight, the angle is called rectilineal. 
10. When a straight line set up on a straight line makes the adjacent angles equal to one another, each of the equal angles is right, and the straight line standing on the other is called a perpendicular to that on which it stands.

11. An obtuse angle is an angle greater than a right angle.

12. An acute angle is an angle less than a right angle.

13. A boundary is that which is an extremity of anything.

14. A figure is that which is contained by any boundary or boundaries.

15. A circle is a plane figure contained by one line such that all the straight lines falling upon it from one point among those lying within the figure are equal to one another.

16. And the point is called the center of the circle.

17. A diameter of the circle is any straight line drawn through the centre and terminated in both directions by the circumference of the circle, and such a straight line also bisects the circle.

18. A semicircle is the figure contained by the diameter and the circumference cut off by it. And the center of the semicircle is the same as that of the circle.

19. Rectilineal figures are those which are contained by straight lines, trilateral figures being those contained by three, quadrilateral those contained by four, and multilateral those contained by more than four straight lines.

20. Of trilateral figures, an equilateral triangle is that which has its three sides equal, an isosceles triangle that which has two of its sides alone equal, and a scalene triangle that which has its three sides unequal.

21. Further, of trilateral figures, a right-angled triangle is that which has a right angle, an obtuse-angled triangle that which has an obtuse angle, and an acute angled triangle that which has its three angles acute.

22. Of quadrilateral figures, a square is that which is both equilateral and right-angled; an oblong that which is right-angled but not equilateral; a rhombus that which is equilateral but not right-angled; and a rhomboid that which has its opposite sides and angles equal to one another but is neither equilateral nor right-angled. And let quadrilaterals other than these be called trapezia.

23. Parallel straight lines are straight lines which, being in the same plane and being produced indefinitely in both directions, do not meet one another in either direction.

\section{COMMON NOTIONS}

1. Things which are equal to the same thing are also equal to one another.

2. If equals be added to equals, the wholes are equal.

3. If equals be subtracted from equals, the remainders are equal. 
4. Things which coincide with one another are equal to one another.

5. The whole is greater than the part.

\section{POSTULATES}

Let the following be postulated:

1. To draw a straight line from any point to any point.

2. To produce a finite straight line continuously in a straight line.

3. To describe a circle with any center and distance.

4. That all right angles are equal to one another.

5. That, if a straight line falling on two straight lines make the interior angles on the same side less than two right angles, the two straight lines, if produced indefinitely, meet on that side on which are the angles less than the two right angles.

This last statement was the source of many a discussion and let to several dramatic breakthroughs later on.

From the very beginning, as we know from Proclus, the Postulate [V] was attacked as such, and attempts were made to prove it as theorem or to get rid of it by adopting other definition of parallels; while in modern times the literature of the subject is enormous ${ }^{17}$.

Postulate 5, better known as Euclid's parallel postulate, has become one of the most famous and controversial statements in mathematical history. It asserts that if two lines $l$ and $l$ are cut by a transversal t so that the angles $a$ and $b$ add up to less than two right angles, then $l$ and $l$ will meet on that side of $t$ on which these angles lie. The remarkable feature of this postulate is that it makes a positive statement about the whole extent of a straight line, a region for which we have no experience and that is beyond the reach of possible observation.

Those geometers who were disturbed by the parallel postulate did not question that its content was a mathematical fact. They questioned only that it was not brief, simple, and selfevident, as postulates were supposed to be; its complexity suggested that it should be a theorem instead of an assumption. The parallel postulate is actually the converse of Euclid's Proposition 27, Book I, the thinking ran, so it should be provable. It was thought impossible for a geometric statement not to be provable if its converse was provable. There is even some suggestion that Euclid was not wholly satisfied with his fifth postulate; he delayed its application until he could advance no further without it, though its earlier use would have simplified some proofs ${ }^{18}$.

\footnotetext{
${ }^{17}$ HEATH, 1956: 202.

${ }^{18}$ BURTON, 2007: 149.
} 
However, the best that could achieved after many tries was to come up with equivalent statements, like the following:

- By a point exterior to a straight line passes exactly one parallel to the line (Playfair);

- The internal angles of any triangle are equal to two right angles;

- Pythagorean Theorem.

Only the 19th century produced mathematicians like Gauss, Bolyai, Lobachevski and Riemann which were able to proof the independence of the 5th Postulate. They proved that when we replace Euclid's postulate by another, keeping the other postulates, we get a consistent set and, accordingly, another geometry. In one case there are infinitely many parallel lines through an exterior point (hyperbolic geometry), in another there are no parallel lines at all (eliptic geometry).

We cannot be too emphatic in stating that Euclid created mathematics as we know it, by writing The Elements, and did so 2300 years ago. Today, with the increasing role of automatic computing, we may foresee a paradigm shift, but our vision blurred and the object is still fuzzy... Euclid lives too strongly inside our mathematical souls. 